\title{
UNITY IN BRITISH PUBLIC HEALTH ADMINISTRATION: THE FAILURE OF REFORM, 1926-9
}

\author{
by
}

\section{FRANK HONIGSBAUM}

EFFICIENT management generally demands unified administration and nowhere is this more important than in the field of public health where failures in co-ordination can prove fatal. Yet when we come to examine the National Health Service, we find it, like Caesar's Gaul, riven into three parts-producing incalculable damage to the maternity and tuberculosis services. Where the hospitals were concerned, there was some cause for separation in 1948. The voluntary hospitals put up such a strong case for it that even municipal hospitals were removed from local authority purview. But when we come to the other two branches of the Service, separation makes less sense. On the face of it, there seems to be no reason why local authority services (clinics, district nurses, midwives, health visitors, home helps) should be set apart from the general practitioner services which rely greatly upon them. Both deal with the same patients in the same community. Divisions created by the insurance principle under the National Health Insurance Act no longer exist-impoverished dependants (not covered by the panel before 1948) no longer have to rely on local authorities and the Poor Law for medical relief. Thanks to Exchequer finance, they are as free to use the general practitioner (and hospital) services as those who are employed. Nor do general practitioners any longer resent clinic encroachment the way they did when private practice played a larger part in their lives. Now that the capitation fee under the Health Service fully protects them, many are only too glad to let local authorities (and hospitals) relieve them of work.

Nor do geographical barriers stand in the way. Local authorities not only cover much the same ground as executive councils (the bodies which administer the general practitioner service) but appoint members to them. The similarity between the two was noted as far back as 1926 by the Royal Commission on National Health Insurance at a time when executive councils were called insurance committees (with somewhat different composition). It saw no reason for their continued separation. ${ }^{1}$ Yet, despite its clear call for unification, nothing was done about it either then or in 1948 when the divisions created by the insurance principle disappeared. This paper attempts to explain why.

INSURANCE COMMITTEES IN HISTORICAL PERSPECTIVE

We begin by placing insurance committees in historical perspective. By 1930, they were the main survivor of the ad hoc principle which characterized British government in the nineteenth century. ${ }^{2}$ School boards were eliminated (in 1902) even before insurance committees were created (in 1911) and the boards of guardians went in 1929. Had all three existed in 1888, one would have thought that insurance committees would be the first to go. Unlike the other two, they never had rate-making power and their areas were almost exactly contiguous with those of local authorities. Furthermore, 


\section{Frank Honigsbaum}

except for the handling of complaints, their duties were unimportant, being largely clerical in nature. They never lived up to the expectations of those who conceived them.

Why, then, were they created at all? In the face of the unification movement which preceded them, it seems hard to understand. This movement really began in 1834 with the epoch-making Poor Law reform since the boards of guardians created then were all-purpose authorities limited only in coverage of population. No other body in British history, in fact, offered such a wide array of social services even if the price in terms of human dignity was high. After 1834, the unification movement was set back by the absence of a single authority outside the municipal boroughs. County councils were not created until 1888. This was the main reason why the Royal Sanitary Commission of 1869 had to restrict itself to central administration. It considered local unification desirable but, in the absence of county councils, it could only produce the Local Government Board. ${ }^{3}$

But from 1888 on (to 1936), the tide toward unification surged forward strongly again. School boards went in 1902 and, though the 1907 school medical service created a further split in public health administration, it was expected to be temporary. In 1909, just two years before insurance committees were created, the Royal Commission on the Poor Laws issued a clear call for unification in public health, on the central as well as the local level. Lloyd George, however, refused to follow that advice mainly because, with friendly societies administering his National Health Insurance scheme, it was impossible for him to do so. This was the first time in British history that voluntary bodies were used on a large scale to provide State services* and their number grew even larger after industrial insurance offices, trade unions and others were added. All, after passing simple tests, could become approved societies and, to supervise them, Lloyd George had to create a new ad hoc body on which they could enjoy representation. Hence arose the National Health Insurance Commissions-one for each 'country' in the British Isles (England, Wales, Scotland, Ireland).**

The same considerations applied on the local level where medical benefit was concerned-only more so. It was impossible to start a new service afresh since the friendly societies had provided one for nearly a century. Yet, their administration of club practice had become a national disgrace which the doctors had failed to rectify after sixteen years of struggle. Most of the other approved societies had no experience of the subject at all, never having offered it on a voluntary basis. Lloyd George had to create a body on which all these various interests could be represented. He therefore set up insurance committees with 60 per cent of the seats going to approved societies and only about 10 per cent to the doctors (the rest being held by local authority and Commission appointees). It was no easy task for Lloyd George to carry the parties even this far. The friendly societies resisted strongly any attempt to take medical benefit from them and Lloyd George had to turn to the doctors for aid. $f$ But it was

\footnotetext{
* Voluntary societies, however, were used on a smaller scale both by the Local Government Board and the Board of Education to provide maternity and child welfare services. Similar provision was made in the case of mental health and welfare of the blind services. Madeline Rooff, Voluntary Societies and Social Policy, London, Routledge \& Kegan Paul, 1957.

** There was also a Joint Committee to lay down policies common to all four.

$\dagger$ For a brilliant analysis of the tortuous negotiations surrounding the Bill, see Bentley Gilbert, The Evolution of National Insurance in Great Britain, London, Michael Joseph, 1966, pp. $289-447$. Much more, however, needs to be said on the subject.
} 


\section{Unity in British Public Health Administration}

impossible to take the next step. Lloyd George hoped to transfer control again before the Bill became law-this time to local authorities. But neither the friendly societies nor the authorities would allow it (the latter largely because it would involve them in extra costs and work).4 A new ad hoc body thus became enshrined in the Act.

Once this happened, central control was inevitable. Local bargaining (between societies and doctors as in club practice) had been envisaged in the original Bill but it was impossible to apply when the employees themselves (i.e. the doctors) secured direct representation on insurance committees. (In addition, they won statutory local medical committees of their own which, over the years, usurped more and more duties from insurance committees). This drained insurance committees of power and made them more like clerical arms of a central department (as in the case of labour exchanges) than independent bodies in their own right. They managed, however, to survive even the demise of the National Health Insurance Commissions (and the creation of the Ministry of Health) in 1919. Local unification was intended then-it was, in fact, closer in 1919 than any time before or since-but the project was postponed after the Poor Law reform failed to carry. Despite unity at the centre, local authorities, insurance committees and boards of guardians went their separate ways.

\section{APPROVED SOCIETIES RESIST UNIFICATION}

This was the situation when the Royal Commission on National Health Insurance issued an insistent call for the absorption of insurance committees by local authorities in March 1926. The merits of the proposal had long been appreciated but the doctors had an additional reason for desiring it. Having just completed thirteen years of struggle over medical benefit, they were anxious to undermine approved society influence. What better way than to transfer control to local authorities? Surprisingly, not only the unions but the friendly societies themselves endorsed the proposal in the hopes of securing an extended medical service. Only the industrial insurance offices were opposed since they had vested interests to protect. If medical benefit were transferred, the cash maternity benefit-which had proved so useful in the purchase of industrial insurance policies-might go too.* Local authorities would then be well placed to expand maternity provision (beyond the clinics already established) inside a unified medical service, reducing the need for cash supplements.

It was not long, however, before the friendly societies changed their mind on the subject. The initial cause was the Economy Act which, by 'robbing' National Health Insurance funds to help pay for the Contributory Pensions Act, drained all hope of extending the medical service. The only way left was by pooling surpluses** but the societies, by then, were in no mood to share their wealth with less fortunate groups (like the unions) in the approved society world.

* Maternity benefit was raised only once during the whole National Health Insurance period1920 , from 30s. to 40s. (or double those amounts if the mother was insured in her own right).

**' Each society had its own fund out of which it paid the 'normal' or statutory benefits. If anything were left over after each valuation (once every five years), then it could provide additional benefits as well. Some societies realized large surpluses while others incurred substantial deficits, producing wide disparities in additional benefits. This led to a demand for equal benefits by sharing the wealth. The Ministry, acting on a recommendation of the Royal Commission, tried to persuade the societies to pool one-half of their surpluses so that all could at least provide specialist and laboratory services as an addition to medical benefit. The friendly societies refused to accept it not only because they were wealthy but because they feared that, once pooling began, it would lead to the end of the approved society system. 


\section{Frank Honigsbaum}

What really galvanized their attitude, however, was the realization of what the doctors were after. The threat implicit in 'unification' did not become clear until the British Medical Association revealed the full import of its proposals before the Royal Commission on Local Government in 1926. Then, in a statement drafted solely by Dr. (later Sir Henry) Brackenbury,* the British Medical Association reiterated its call for the abolition of insurance committees but carefully excluded any mention of approved society representation on the new local authority bodies which would administer the service. Each authority would be compelled to form statutory health committees and, though the doctors were willing to accept minority representation, they wanted all the remaining members to be appointed by the local authority, room being left for others (who would be co-opted) only on the sub-committees created to deal with special subjects like National Health Insurance. Brackenbury, however, preserved a place for local medical committees which would not only appoint all medical representatives as before but would enjoy the right to present their views directly to local authorities, the Ministry and the public. ${ }^{5}$ Furthermore, their operating expenses would no longer be defrayed by the profession but would be borne by local authorities, thereby prompting the National Insurance Gazette (the voice mainly of the offices in the approved society world) to cry: 'The doctors want a local trade union, to be paid for by the public!"•

The memorandum created an uproar among the approved societies, even those run by the unions. One official thought 'they could not shut their eyes to the fact that the British Medical Association was becoming obnoxious'.7 Another saw in the statement an attempt by the doctors 'to get the whole control of the medical service in their hands', pleading with his colleagues not to 'damn National Health Insurance' by giving local authorities, who 'already had more work than they could carry out', a chance to abdicate responsibility. ${ }^{8}$ Still another feared the fate of the mixed laymedical complaint-hearing bodies (medical service sub-committees) if administration were transferred to local authorities, singling out the British Medical Association's demand (to the Royal Commission on National Health Insurance) for a purely professional tribunal 'as about the most audacious proposal ever made'.

It took Henry Lesser** of the employer-sponsored approved society group, however, to unravel the full implications of the statement:

... while insurance committees were to go, local medical committees under another name were to remain - a rather thin disguise ... the local medical committee was to be absolutely independent of the local authority who, however, were to be responsible for its administrative expenses.

- Brackenbury was a general practitioner from Hornsey who, by 1926 , had accumulated more than 27 years' experience in local government. Together with Dr. Alfred Cox, Medical Secretary, he dominated British Medical Association policy between the wars. He died in 1942. Alfred Cox, Among The Doctors, London, Christopher Johnson, 1950, pp. 105-6.

** Lesser, who qualified as a barrister in 1913-4, took no part in the negotiations on the Bill but became prominent in National Health Insurance shortly thereafter, acting on behalf of the employees' approved society organized by the South Metropolitan Gas Co. He spoke for the anti-union employers in the approved society world, leading the various attempts made by them to undermine union influence in the social insurance field, and to forestall the 'nationalization' of National Health Insurance. He was also one of the leaders of the London Insurance Committee throughout the entire National Health Insurance period. When the approved society system passed away in 1948, he became a consultant on occupational pensions, acting also as adviser on that subject for the Conservative Party in the 1950s. He died in January 1967. 


\section{Unity in British Public Health Administration}

He was not sure whether they ought to take this document seriously. From a constitutional point of view, it was worthy not of the twentieth century, but of the Middle Ages. According to the British Medical Association, insured persons and employers were to pay for the costs of panel treatment, but were to have no controlling voice in its administration while the doctors were to be free to appoint whom they pleased. The approved societies were rather contemptuously dismissed from the game altogether. At present the societies were the only bodies standing between the insured persons and the panel doctors. They had a right to be heard in complaints before medical service sub-committees and through their representatives on the local insurance committees, were enabled to keep a watchful eye on the administration of medical benefit generally. The doctors apparently wanted to put an end to this. Hence their demand for the abolition of the local insurance committees. ${ }^{10}$

There had been frequent clashes in the past between approved societies and insurance committees (despite their 60 per cent society majority) over the administration of additional treatment benefits.* But the threat to abolish insurance committees repaired the breach, for it forced the societies to realize how much their own existence was intertwined with that of insurance committees. ${ }^{11}$ The creation of a unified health service, part of which would be financed on a tax or rate basis, would be 'a distinct step in the direction of nationalisation' and 'the disintegration of the insurance principle'. ${ }^{12}$ This led the societies to have doubts about the wisdom of 'extension' too for, as the Commission had warned, 'we feel sure that the wider the scope of these services, the more difficult will it be to retain the insurance principle'. ${ }^{13}$ And once the insurance principle went, so would go the case against equal benefits for even the leader of the offices (Sir Thomas Neill) had acknowledged the justice of the latter once Exchequer finance took over. ${ }^{14}$

To Henry Lesser, 'The whole thing savoured of the Poor Law'. Approved societies, he argued, needed to keep National Health Insurance 'a separate entity' in order to preserve their own lives: 'The twin pillars of that scheme were the approved societies and the insurance committees. If they smashed one of those pillars, they could not expect the other to support the superstructure.'15 By the time the Government came to draft the 1928 National Health Insurance Act, then, the societies had made their position clear-they did not want 'unification' at any price.

Neville Chamberlain, then Minister of Health, swiftly accommodated them. This surprised many, for the Ministry had come out strongly for unification before the Royal Commission on National Health Insurance. ${ }^{16}$ It was needed urgently in the maternity services where the division between National Health Insurance, local authorities and the Poor Law was thought to be partly responsible for the high mortality rates then prevailing. Baldwin (then Prime Minister), it was true, had ruled out any reforms that cost money but this, far from draining funds, was designed to save them. ${ }^{17}$ To understand why the Conservatives changed their mind on the subject, we need to go back a few years.

* Since insurance committees were given control of medical benefit in 1911 , they thought they would administer any additional benefits in the form of treatment too-and on this they received the strongest support from the doctors. The approved societies, however, decided otherwise, dissatisfied as they were with the administration of medical benefit, and the Ministry let them get away with it. This led to a series of angry clashes between 1921 (when additional benefits began) and 1926, erupting most damagingly in the 1923 pay dispute and before the Royal Commission on National Health Insurance. Medical influence on insurance committees, far greater than its 10 per cent proportion would imply, helped committee clerks to override the protests of the 60 per cent society majority. 


\section{Frank Honigsbaum}

Even before the Commission sat, the Government planned to proceed with the 'unification' programme which had been dropped in 1920. Chamberlain, in fact, had laid down a timetable of reform which called for the abolition, first, of the guardians (in 1926) and then of insurance committees (in 1927), thereby eliminating the overlap from both sources and removing the 'taint' of the Poor Law from the Ministry. ${ }^{18}$ Among other factors, however, the resistance of the guardians upset the timetable and the Government did not complete its plans to abolish them until 1928. ${ }^{19}$

The delay gave the approved societies the breathing-space they needed to save insurance committees and they were aided not only by the Government's guilt over the Economy Act but by the offices' considerable influence in the Conservative Party, increased no doubt by the elevation of Sir Kingsley Wood* to Parliamentary Secretary of the Ministry of Health in November, 1924. Judging from the way the question was allowed to recede quietly in the background of the 'pooling' dispute, the Government probably called off its plans to abolish insurance committees early in 1927 but delayed public announcement long enough to assure the end of the guardians. ${ }^{20}$ It was possible, of course, to eliminate one without the other but the plans to kill both had become linked in the 'extension' programme. ${ }^{21}$ Logically, 'unification' did not depend on 'extension' but, with so many vested interests involved, the Government realized that it would be difficult to force through the former without the latter. The profession itself had forged the tie between the two concepts in 1923 when, in view of the economic conditions then prevailing, it told the societies that the only hope of 'extension' lay through 'unification' ${ }^{22}$ This was why the friendly societies assumed that insurance committees would be saved after they rejected 'pooling', which no doubt influenced their decision on the subject. ${ }^{23}$

Nevertheless, while they retained insurance committees, the Tories went ahead with their plans to abolish the guardians, if only to forestall wider reform by a Labour Government. For this reason also, the approved societies accepted the Local Government Act of 1929. Notwithstanding its tendency toward 'a clean sweep of all public health schemes into the hands of local authorities', for the moment at least the Act meant 'a period of subsequent peace'.24

Local authority attitudes also influenced the Government's decision. Here there was a sharp difference of opinion between medical officers of health and other local authority personnel. For medical officers of health the 1929 Act presented a great opportunity: it promised to accelerate the slow growth in whole-time appointments** and close the gap between curative and preventive medicine. Not only hospitals but

* Wood, a solicitor, represented the offices during the negotiations on the 1911 Bill and his firmWood, Williams and Murphy-continued to act for them throughout the entire National Health Insurance period. Wood was active on the London County Council and London Insurance Committee from 1911-2 but he did not win national attention until 1917 when he drew up a scheme for a Ministry of Health on behalf of the approved societies. In 1919, he entered Parliament and stayed there until his death in 1943 when he was Chancellor of the Exchequer. He held all three political posts at the Ministry of Health: Parliamentary Private Secretary to Dr. (later Lord) Addison, 1919-22; Parliamentary Secretary to Neville Chamberlain, 1924-9; and Minister in his own right, 1935-8.

** There was a sharp increase in the number of whole-time appointments following the 1909 Housing and Town Planning Act. But, between then and 1928, there was hardly any increase at all, the total hovering around 350 out of 1,233 . This was only about a 29 per cent proportion-compared with 25 per cent (out of a much smaller total number) in 1873. Brit. med. J., 1928, if, 575-6 (Robinson). Lancet, 1928, ii, 875. For a full list showing which authorities employed whole-time, and which parttime, medical officers of health in 1929, see Nursing Notes, 1929, pp. $20-1$. 


\section{Unity in British Public Health Administration}

now, for the first time, domiciliary care was within their grasp. Due to British Medical Association action, the latter had been barred under the Public Health Acts from 1918* but the transfer of the Poor Law brought domiciliary care for paupers under their control and they wanted to extend coverage to insured persons. The high maternal mortality rates, above all else, was what spurred them. They wanted to remove cash payments from the grasp of greedy industrial insurance agents. ${ }^{25}$

As in 1911 and 1919, however, clerks and councillors felt differently. Already overburdened with preparation for the Poor Law, they had no wish to take on more, particularly in an area where they had no experience and which would involve them in delicate disputes with doctors.** Furthermore, they were afraid of being made to meet the costs of administration. ${ }^{26}$

\section{DOCTORS CHANGE THEIR MINDS ON UNIFICATION}

In terms of future development, however, the most relevant-and revealing-part of the whole story was the transformation of medical attitudes. To the astonishment of everyone, the doctors stifled their cry for 'unification' at the critical moment. They had welcomed the abolition of the guardians in the hope not only of stopping the movement, long underway, toward a whole-time Poor Law service but also of removing the danger, in a few areas, of approved society influence on the guardians. ${ }^{27}$ With the co-operation of sympathetic medical officers of health, like Dr. (later Sir John) Charles of Newcastle (who, in 1950, became Chief Medical Officer of the Ministry of Health), they did, in fact, manage to introduce the principle of free choice into the Poor Law. $\dagger$ But not all medical officers of health agreed with British Medical Association policy and the profession feared the creation of a salaried service if it pushed ahead with 'unification' too far and too fast. The Government, it was true, assured the doctors of its opposition to such a system ${ }^{28}$ but there was always the chance that Labour might return to power-and British Medical Association influence in the Labour movement (earlier, quite strong) was, at this moment, on the wane.

Furthermore, as Ministry spokesmen proclaimed before the Commission, circumstances might force any Government (local or national) to adopt it. Mr. (later Sir Laurence) Brock, Assistant Secretary of the Ministry, believed this might happen merely if dependants were added to the panel: ' . . the whole basis of payment and method of organization of that service would be required to be reviewed, and although I am not expressing any opinion in favour of a salaried service, at any rate it would be a matter for serious consideration as to whether the demand might not be met more

- Both the Acts passed in 1918 (Education as well as Maternity and Child Welfare) contained bans against a general domiciliary service for mothers and children. But, it is important to note, the 1919 Statute creating the Ministry of Health left the Minister free to introduce a salaried service by Regulation - and this power remained in the Act throughout the entire National Health Insurance period.

** Only the London County Council was willing to take on the job-not the other authorities. I am indebted to Sir Allen Daley (the former Medical Officer of Health of the London County Council) for calling the opposition of the authorities to my attention. Letter to writer, 31 January 1962.

$t$ This was proposed by the British Medical Association as early as 1839 and recommended by the Majority on the Poor Law Commission in 1905 but it was not implemented anywhere until 1927. Even then, it did not make much progress until Dr. Charles took it up in 1933. Brit. med. J., 1926, ii, 377-8 (Martin); 1929, ii, supp., 221-3 (Snell); 1933, i, supp., 172-3 (para. 105), 249-50; 1934, i, 386; 1934, i, supp., 1-2, 9-10; 1935, i, supp., 125-6 (Charles), 139.

Lancet, 1936, i, 1439-40; 1937, i, 167-8. 


\section{Frank Honigsbaum}

economically by the provision of a salaried service.'29 ${ }^{2}$ The same, said another Ministry spokesman, might happen with the addition of institutional services, since Poor Law, as well as tuberculosis and maternity experience, suggested the need for 'close coordination between the institutional and domiciliary staffs, and it is doubtful whether co-ordination could be secured if the scheme in view is to cover both and a free choice of doctor is to be maintained.' 30

The doctors also felt uneasy simply about being brought into close relationship with local authorities and medical officers of health. Here, however, opinion was divided and ambivalent, concerned above all with the role played by medical officers of health. Should they be whole-time or part-time? The British Medical Association had long stood for the whole-time principle and the Royal Commission on Local Government came out for the same policy. ${ }^{31}$ But Brackenbury, from his long experience in local government, had come to see the contradiction between this and the British Medical Association's demand for part-time general practitioners to staff local authority clinics. ${ }^{32}$ Whole-timers preferred to work with whole-timers-yet the British Medical Association had to extend the part-time principle if only to enable general practitioners to serve on local authorities. With 'unification' imminent, this question assumed great importance. How else could the profession secure the same representation on local authorities as it enjoyed on insurance committees? At the moment, it was true, part-timers were also barred from office but the Royal Commission on Local Government promised to remove the ban.* The whole-time medical officer of health who refused to employ part-time general practitioners then, was the major obstacle in the way. Brackenbury saw that the British Medical Association would have to reverse its policy on the subject, particularly after its rival, the Medical Practitioners' Union, ${ }^{* *}$ came out openly for part-timers. ${ }^{33}$

How, however, could it do so without antagonizing whole-time medical officers of health and their Society? There was no question of displacing those who already enjoyed whole-time status. In any event, since they were found in populous areas, they rarely came in contact with general practitioners. The problem centred, rather, on the smaller authorities-boroughs and urban district councils-within the county council areas. There the part-timer still reigned and Brackenbury wanted to preserve his place. He did this in a subtle manner-by defending the right of the smaller authorities to act without county council control as they did in the field of education. ${ }^{34}$ As long as they operated autonomously, they would find it uneconomical to make whole-time appointments. But even if that strategy failed, he was willing to risk 'unification' if only to stop further encroachment from local authority clinics on general practitioner work. He had come out strongly for dependent coverage under National Health Insurancess but, since that had been ruled out on grounds of cost,

* The ban was eventually relaxed in the 1933 Local Government Act but not as much as the British Medical Association hoped. It applied only to doctors serving part-time in clinics, not district medical officers under the Poor Law even where free choice had been won. By 1936, only 150 doctors had been elected to 120 authorities and not all, by any means, followed British Medical Association policy. Brit. med. J., 1936, ii, supp., 258-9; 1942, i, supp., 53, 81-3.

* Despite its much smaller membership (2-3,000 compared to 30,000), the Medical Practitioners' Union was a thorn in the British Medical Association's side throughout the National Health Insurance period. It spoke, by and large, for the more militant panel general practitioner - one who had little private practice-and repeatedly accused British Medical Association leaders of 'selling out' to the Ministry, thereby forcing them to adopt more extreme positions than they considered desirable. 


\section{Unity in British Public Health Administration}

who knew where the new powers added by the Poor Law would lead medical officers of health? The only way general practitioners could protect themselves, he argued, was within a unified service-by offsetting the influence of medical officers of health on local authority policy.

Dr. (later Sir Guy) Dain, * however, was unwilling to take the gamble-and he had a large following in British Medical Association circles. The profession knew where it stood, he argued, with insurance committees but not with local authorities: 'There was a tremendous disinclination on the part of the general practitioner to being in the employment of the medical officer of health and of the health committees as at present constituted.'36 The Medical Practitioners' Union shifted uneasily back and forth between these points of view. On the one hand, it saw 'unification' as a way for general practitioners to secure access to Poor Law hospitals-and it also thought it could negotiate higher rates for specialist care (if ever added to the panel) from local authorities than from a society-influenced administration. ${ }^{37}$ On the other hand, it feared the political bias of many councillors and shared Dain's doubts about the advantage of complete 'unification'. In the end, it came down on the side of 'coordination' rather than 'unification', calling for the end of only approved societies, not insurance committees. ${ }^{38}$

Chamberlain's Local Government Act did much to confirm Dain's fears. In contrast to National Health Insurance, the statute was inspired by the doctrine of local control. Largely because of their rate-making power, local authorities had always enjoyed more freedom than insurance committees. As far as public health was concerned, the only real departmental lever over their work had come in the form of percentage grants designed to stimulate the development of specific services like maternity and child welfare. Most amounted to 50 per cent, but, for venereal disease, they ran as high as $\mathbf{7 5}$ per cent. Newman attached the highest value to this device but Chamberlain did not. Like the Geddes Committee (which wanted to cut the rates to 5 per cent in 1922), he felt the Ministry had inherited a burden of indiscriminate grant-giving left by the Local Government Board (when it was absorbed in 1919).** In the 1929 Act, therefore, he reversed the whole tendency toward central control by substituting block grants (fixed for five-year periods) which left local authorities considerable discretion as to how the money would be spent. The only safeguard he inserted was the power to reduce the grant if, upon investigation, the Ministry found services to be inefficient. ${ }^{39}$ Since the British Medical Association had always been stronger at the centre than the periphery, this change threatened to undermine its influence in a unified service. Insurance committee subservience to the Department was much more compatible with the pattern of British Medical Association power ${ }^{10}$ as well as with the profession's desire to be free from supervisory control: ' . . . the local representatives are too much in our midst, and we shall be worried by their day-to-day interference'. ${ }^{11}$

- Dain, a Birmingham general practitioner, was Brackenbury's main rival for the leadership of the British Medical Association between the wars. He qualified in 1893 but did not play an active role in British Medical Association politics until the War. On several occasions he challenged Brackenbury's policy with success (as in this instance) but never displaced him from leadership. After Brackenbury died in 1942, Dain emerged as the chief negotiator over the Health Service, remaining active in the British Medical Association almost until his death in 1966.

** The main abuse, it was thought, came on welfare milk schemes. Lancet, 1922, i, 383. 


\section{Frank Honigsbaum}

The same philosophy inspired Chamberlain's reform of the Poor Law. While the guardians were abolished, local authorities were given enough discretion to continue the Poor Law virtually intact. It was true that they were directed to remove as many functions from the Poor Law as possible but no specific provision was made to see that this was carried out. Instead, the authorities were merely instructed to form public assistance committees to which all Poor Law duties were assigned en bloc. It was then possible for another transfer to take place-to one of the functional committees of the council (like the public health committee) which would, in effect, remove the service from the Poor Law. But this move could all too easily be blocked by the opposition of public assistance committees. In the case of the hospitals, the transfer did not have to be total; some could be taken out of the Poor Law while the others were left. But no such choice was permitted with the district medical service. It had to remain under the Poor Law and only the protests of the British Medical Association forced the Ministry to shift supervisory control from a lay official to the medical officer of health. ${ }^{42}$

This right of local option ruled out any statutory protection for the profession, either in the form of local medical committees or representation on the public health committee. Had all the medical services of the Poor Law been transferred to the latter in one swoop, then Parliament might have granted the British Medical Association's demands. But before that could have happened, it would have been necessary to decide the form the domiciliary service should take. Would all local authorities be willing to continue the panel system-or would they opt for the salaried medical service under the Poor Law in some areas? The British Medical Association thought it safer not to raise the question at the time. It already had protection, under the 1918 legislation, against a salaried service outside the Poor Law (and this was continued in the 1929 Act). Was it not wiser to leave the district medical services intact and then fight the issue out area by area? Paradoxically then, the British Medical Association was partly responsible for the rejection of its own demands.

Thanks to Lord Dawson, * the Act was amended so as to give the voluntary hospitals (though not necessarily the profession) the right of consultation over hospital administration-but this did not apply to other medical services, whether under the Poor Law or not. ${ }^{43}$ Furthermore, despite its support for co-option before the Royal Commission on National Health Insurance, ${ }^{44}$ the Ministry refused to compel it on either public assistance or public health committees. As on all the committees of the council (except finance), as many as one-third of the members could be co-opted if the authority desired but no orders were issued on the subject. Instead, the Department decided merely to give advice. Even then, it did not single out doctors for co-option, urging public assistance committees to enlist the aid only of persons with Poor Law experience. As far as public health committees were concerned, a British Medical Association survey showed that 'a very large number' made no provision at all for co-option, not even Brackenbury's own Middlesex County Council. Doctors in the

\footnotetext{
* Bertrand Dawson was a prominent physician who played a leading role in medical politics from 1917 until his death in 1945, both in the British Medical Association and in the Royal College of Physicians. He was the Chairman of the Ministry Committee that produced the famous Dawson Report in 1920 in which the idea of health centres first received official sanction. For an account of his life, see Francis Watson, Dawson of Penn, London, Chatto \& Windus, 1950.
} 


\section{Unity in British Public Health Administration}

employ of the authorities, whether part-time or whole-time, were still barred from office, the Act going so far as to threaten the displacement of some doctors already elected. As Brackenbury complained, medical men did not enjoy the same rights as teachers. The latter, in some areas, had been given representation on education committees but this did not apply to doctors and public health committees. ${ }^{45}$

The profession here ran up against the same Local Government Board tradition which plagued the approved societies earlier on local authority pension, maternity and tuberculosis committees. The words of Sir Alfred Mond (later Lord Melchett) in 1921 (rejecting an attempt to compel the co-option of insurance committee members to tuberculosis committees upon the transfer of sanatorium benefit) returned now to haunt the doctors: 'I cannot see my way, and I do not think anyone standing in my position could see his way, to force a local authority which is elected by the ratepayers to conduct a certain service, to co-opt members on a committee which is dealing with such a service, whether they want them there or not.' ${ }^{46}$ In any case, he asserted, experts should not be given executive authority-and here he was only echoing one of the unwritten rules of British government. Labour, too, had opposed co-optionbut for a different reason: it wanted to keep the reactionary guardians out of Poor Law administration. But the effect of the Conservatives' policy was to turn public assistance committees into little more than boards of guardians with a new name. ${ }^{47}$

In addition, the Act failed to preserve the independence of boroughs and urban district councils as Brackenbury hoped. Here he was running counter to progressive thought. Some county councils, it was true, left much to be desired and the power which the block grant gave them needed to be watched. Not all the smaller authorities, furthermore, were impotent. Dr. L. J. Picton had demonstrated what good an urban district council could do both for the public and the profession. As panel doctor and part-time medical officer of health at Winsford, he persuaded the Council not to establish ante-natal clinics but to let general practitioners do the work in their own surgeries. The experiment worked so well that it was later extended to the county (Cheshire) as a whole. ${ }^{48}$ This was the policy the British Medical Association wanted the nation to follow and no doubt the course of public health history in Britain would have been different had it succeeded. But not all part-time medical officers of health were as energetic as Picton and too many smaller sanitary authorities had neglected to exercise the duties placed on them. They badly needed the spur which only a full-time medical officer of health could give. The Act, therefore, subjected them to the supervision of county councils which, in turn, were directed to introduce the whole-time principle through the medium of joint employment schemes.* This led to the growth** of the whole-time public health corps in the 1930s which, despite Brackenbury's heroic efforts at conciliation, drove the profession further apart and set the stage for the rejection of health centres, salary and control by medical officers of health in the 1940s.

* These schemes, which started in 1912, called for the combination of districts or appointments (i.e. assistant county medical officer of health and district medical officer of health). Medical officers of health preferred the first method; the Ministry, the second. Public Health, July, 1928, pp. 299-300; March, 1931, pp. 161-2.

** The growth, however, was not as rapid as expected. As late as 1938, many county councils had still not appointed whole-timers for districts as the Act directed. Medical Officer, 1938, i, 2. 


\section{Frank Honigsbaum}

Even with the rejection of their other demands, the doctors might have been willing to gamble on 'unification' in 1929 if local medical committees had found a place in the Act. They felt they could live without direct representation on local authorities but not without the statutory bodies they fought so hard for in $1911 .^{49}$ Once local medical committees went, the doctors lost their enthusiasm for 'unification' and, in so doing, they revealed the extent to which their attitude had changed since 1923. Their 'glorious victory' in the decisive pay dispute of that year had wrought a revolution in approved society/medical relations which the profession was only just beginning to perceive. Approved society power was waning fast. At that moment, in fact, a solution to the profession's long-standing grievances on the disciplinary procedure was in sight. The doctors thus had less to fear from insurance committees than from local authorities.

By the 1940s, this had become clear even to the most unpolitical general practitioner. Approved societies, thanks to the Beveridge Report and the 1945 Labour Government, disappeared for ever from social insurance as well as from insurance committees. Their places on the latter-now called executive councils-were taken by the 'neutrals' of the past, the public (local authority and Ministry) appointees. In addition their number was cut from an overwhelming (60 per cent for approved societies, 90 per cent for all lay persons) to a bare lay majority as on medical service sub-committees. Executive councils, in fact, became little more than 'lay fronts' for local medical committees. Was it any wonder that, in 1942-4,the doctors rejected any thought of local authority control?

Now, twenty-five years later, the situation is different. General practitioners no longer fear clinics and they have forgotten the clashes of the past. Some distrust still lingers, but the two branches of the profession are being driven together by manpower shortages and the demands of community medicine. General practitioners can no longer do without the aid that only medical officers of health can offer, particularly in the form of district nurses, midwives, health visitors and home helps. The time is ripe for integration, if not unification, between two branches of the Service and other pressures-notably the need for shorter bed stays-are pushing hospitals in the same direction. Complete structural integration will take time to realize, depending above all on the creation of larger regional forms of government. But the history of the attempt made in 1926-9 offers some guide as to the kind of security the profession needs before it will risk abandoning what it has now.

\section{REFERENCES}

1. Report of the Royal Commission on National Health Insurance, London, H.M.S.O., 1928, Cmd. 2596, pp. 165-74.

2. Smellie, K. B., A History of Local Government, London, Allen \& Unwin, 1957, pp. $22-41$.

3. Ibid., pp. 42-57.

4. Parliamentary Debate, House of Commons, Hansard, vol. 30, col. 1682, 8 November 1911 (Forster).

5. Brit. med. J., 1926, i, supp., 36-9.

6. Natn. Ins. Gaz., 1926, p. 427.

7. Ibid., p. 96 (Squire).

8. Ibid., p. 100 (Griffin). 


\section{Unity in British Public Health Administration}

9. Oddfellow's Mag., 1926, pp. 433-4 (Davies).

10. Natn. Ins. Gaz., 1926, p. 98. See also Brit. med. J., 1926, i, supp., 65, 91.

11. Natn. Ins. Gaz., 1926, p. 511.

12. Ibid., p. 127.

13. Report of the Royal Commission on National Health Insurance, 1928, p. 65.

14. Ins. Mag., January 1925, pp. 21-3.

15. Proceedings of the National Association of Insurance Committees, 1926, p. 11.

16. Report of the Royal Commission on National Health Insurance, 1928, pp. 54, 171-3.

17. Ibid., pp. 311-2.

18. Feillng, Kerth, The Life of Neville Chamberlain, London, Macmillan, 1946, pp. 459-62.

19. Natn. Ins. Gaz., 1925, pp. 618-9; 1927, pp. 19, 247.

20. Natn. Ins. Gaz., 1927, p. 607.

21. Natn. Ins. Gaz., 1926, p. 475.

22. Brit. med. J., 1923, i, 248-9.

23. Natn. Ins. Gaz., 1926, p. 499.

24. Natn. Ins. Gaz., 1928, pp. 257, 331, 583.

25. Report of the Royal Commission on National Health Insurance, 1928, p. 51. Brit. med. J., 1930, i, 753-5.

26. Oddfellow's Mag., 1926, pp. $433-4$ (Davies). Med. Wld., 10 June 1927, pp. 267-8.

27. Brit. med. J., 1920, ii, 140-1 (Green); 1920, ii, supp., 109-10; 1924, i, supp., 138 (Sunderland).

28. Brit. med. J., 1926, ii, 794; 1927, i, 344; 1927, ii, 744-5.

29. Royal Commission on National Health Insurance, Minutes of Evidence, Q. 23, 847, 1928.

30. Ibid., Q. 24,067-9, 24,128-38, 24,155, 24,177-80 (Maclachlan).

31. Brit. med. J., 1928, ii, 800-1.

32. Med. Offr., 1934, i, 151.

33. Med. Wld., 29 March 1929, p. 63.

34. Brit. med. J., 1926, i, 36-9; 1926, ii, 382-3; 1926, ii, supp., 75-9; 1928, ii, supp., 142-3.

35. Brit. med. J., 1925, i, supp., 39-41.

36. Brit. med. J., 1926, ii, supp., 77-8.

37. Med. Wld., 2 April 1926, pp. 127-8; 9 July 1926, 385-402 (Gregg).

38. Med. Wld., 30 November 1923, pp. 318-21. Royal Commission on National Health Insurance, Minutes of Evidence, App. 48, para. 19, 21-2, 25; Q. 15, 554-5, 15, 534, 1928.

39. Smellie, 1957, pp. 132-9. Abel-Smith, Brian, The Hospitals, London, Heinemann, 1964, pp. 358-63.

40. Brit. med. J., 1930, ii, supp. 86-7 (Brackenbury). Natn. Ins. Gaz., 1936, pp. 596-7 (Dain).

41. Mackintosh, J. M., Trends of Opinion about the Public Health, 1901-51, London, Oxford University Press, 1953, p. 137.

42. Brit. med. J., 1928, i, 854-5, 997-8; 1929, i, 360; 1930, i, 453-4, 604. WEBB, SIDNEY, and WebB, Beatrice, English Poor Law History: Part II: Last Hundred Years, London, Longmans, Green, 1929, pp. 986-8. MACKINTOSH, 1953, pp. 141-4. SMELlIE, 1957, pp. 75, 101, 111. AвEL-SMTTH, 1964, pp. 360-1.

43. Brit. med. J., 1929, i, 463, 514, 651.

44. Report of the Royal Commission on National Health Insurance, 1928, p. 173.

45. Brit. med. J., 1927, i, 1073-4; 1929, i, 735; 1929, ii, 1213-5; 1929, ii, supp., 91 (Brackenbury), 190, 209; 1930, i, supp., 143-4 (para. 145-51); 1933, i, supp., 249-51.

46. Parliamentary Debate, House of Commons, Hansard, vol. 140, col. 1146, 13 April 1921.

47. Brit. med. J., 1930, i, 453-4. ABEL-SMrTH, 1964, p. 362.

48. Brit. med. J., 1936, ii, 360-1.

49. Brit. med. J., 1927, i, supp., 152 (para. 150-4); 1929, i, supp., 117 (para 124). 